\title{
Hypoglycemic Drugs and Advanced Glycation Endproducts
}

\author{
Wen Xiong ${ }^{1}$, Zhiqiang Zhou ${ }^{2}$, Xiandang Zhang ${ }^{3}$ \\ ${ }^{1}$ Deputy chief physician, Master of Medicine, Shandong Institute of Endocrinology and Metabolic Diseases, \\ ${ }^{2}$ Chief technician, Department of Pathology, Qilu Hospital of Shandong University. \\ ${ }^{*}$ Professor, Shandong Institute of Endocrinology and Metabolic Diseases. \\ *Corresponding Author: Xiandang Zhang, professor, Shandong Institute of Endocrinology and Metabolic Dis- \\ eases, China.
}

Abstract

Recent data showed that $9.1 \%$ of adults worldwide have diabetes, and 318 million adults have a high risk of developing diabetes in the future. Diabetes and its complications have serious impact on human health. In the early stages of diabetes, excessive advanced glycation endproducts (AGEs) accumulate in the body and bind to its receptor RAGE, which impairs glucose regulation. In the later stages of diabetes, increased blood glucose can accelerate the production of more AGEs. AGEs play a pivotal role in the development of diabetes and its complications. In recent years, AGEs have become one of the research hotspots. The search for potential drug targets that can block or reduce the accumulation of AGEs has attracted increasing attention. This review summarizes the role of AGEs and the effects of various hypoglycemic agents on AGEs from the perspective of mechanisms, in order to provide reference for the further search for targeted drugs against AGEs.

Keywords : AGEs; Diabetes; Complications; Hypoglycemic drugs; Mechanism; Targets.

\section{BACKGROUND}

According to the latest report of the International Diabetes Federation Diabetes Atlas [1], 415 million adults in the world have diabetes, corresponding to an overall incidence rate of $9.1 \%$, and 318 million adults have impaired glucose regulation with a high risk of developing diabetes in the future. China is the country with the largest number of diabetic patients in the world. According to a published national survey, the prevalence of diabetes in China has increased dramatically over the past 30 years: from less than $1 \%$ in 1980 , to $5.5 \%$ in 2001 , and $9.7 \%$ in 2008 . In the 2013 survey, it is estimated that the prevalence of prediabetes in China will reach $35.7 \%$. [2]

Advanced glycation endproducts (AGEs) are a series of stable and irreversible covalent compounds (such as carboxymethyl lysine, 3-deoxy glucosanoic acid, pentosidine, pyrroline, glyoxal) produced by the reaction of the aldehyde groups of the reducing sugars with the free amino groups of the macromolecules (proteins, lipids, or nucleic acids, etc.) in non-enzymatic conditions, involving processes of condensation, rearrangement, cleavage and oxidative modification [3]

Several studies have shown that AGEs are involved in the occurrence and development of chronic complications of diabetes, atherosclerosis, uremia, Alzheimer's disease, and cataracts.[3-7] AGEs are important pathogenic factors in the pathogenesis of atherosclerosis [8], diabetes [9], diabetic nephropathy [10], cataract [11] and neurodegenerative diseases (including Alzheimer's disease)[12].

Unreasonable dietary structures, increased oxidative stress in the body, decreased deglycosylation ability, and long-term hyperglycemia can all lead to accelerated accumulation of AGEs. In the early stage of diabetes, excessive accumulation of AGEs in vivo and the interaction of AGE and its receptor RAGE can lead to apoptosis and necrosis of islet $\beta$ cells, insulin resistance, and impaired glucose regulation.[13] In the middle and later stages of diabetes, the continuous increase in blood glucose can accelerate non- 
enzymatic chemical reactions in the body and produce more AGEs. Therefore, there is a higher level of serum AGEs in diabetic patients [14] and these excess AGE will accumulate in the body and attach to cells. The level of diabetic AGEs in the vascular endothelial cells, nerve cells, kidney tissue, lens and other body tissues is also higher than that in the normal population. [14-17] AGEs can cause the development of diabetic complications through direct or indirect actions.

\section{AGEs Mechanism of ACTION}

\section{Three Main Mechanisms for Age-Mediated Tissue Effects}

(1) Cross-linking with extracellular (matrix) proteins affects the mechanical properties of tissues. [18] The formation and accumulation of cross-linked extracellular matrix proteins with AGE is a chronic process. Extracellular matrix proteins, especially the long-lived protein type IV collagens of basement membrane are more susceptible to glycosylation.[19, 20] Advanced glycosylation and cross-linking make other extracellular matrix proteins (such as collagen I and elastin) stiffer and less susceptible to degradation .[18] This mechanism may contribute to increased diabetes and vascular stiffness in the elderly .[18, 19, 21] The structure of low-density lipoprotein (LDL) can also be altered by the glycation of AGE, preventing normal elimination pathways from removing them from the circulation. Instead, they are taken up by blood mononuclear cells to form foam cells, resulting in the development of atherosclerosis. [5, 22]

(2)Cross-linking with intracellular proteins, altering the physiological properties and functions of the cells. [23, 24] For example, AGEs cross-link the domains of Ryanodine receptor [23] and SERCA2a [24] in cardiomyocytes, leading to altered calcium homeostasis in diabetic cardiomyopathy. [25, 26]

(3)Binding to cell surface receptor RAGE to induce multiple intracellular signal transduction cascades. [27] It has been shown that there is a nuclear factor kappa B (NF-kappa B) binding site on the promoter of RAGE gene, thus linking RAGE expression with the inflammatory cascade. [28]

\section{RAGE}

RAGE is a multi-ligand receptor for AGEs. RAGE is upregulated in a ligand-rich environment of diabetes or aging. The expression of RAGE is even more elevated in monocytes, smooth muscle, and endothelial cells at the diabetic vasculature.[29] It has been shown that circulating AGEs bind to endothelial RAGE and activate many signaling pathways, such as activation of nicotinamide adenine dinucleotide phosphate oxidase leading to increased reactive oxygen species (ROS) production and impaired endothelial function.[30] ROS have been shown to play a key role in causing significant cardiovascular damage in diabetes by altering the structure of cellular nucleic acids, proteins, and lipids, thereby altering their physiological function.[31] It has been reported that AGE-RAGE is involved in the process of increasing the phosphorylation of mitogen-activated protein kinase, extracellular signal-regulated kinase $1 / 2$ and p21ras, p38, activating the GTPases Rac and Cdc42. These effects ultimately induce the activation and the nucleus translocation of NF-KB and subsequently initiate the transcription of cytokines and adhesion molecules that play a major role in inflammation and atherosclerosis (including intercellular adhesion molecule-1, vascular cell adhesion molecule-1, vascular endothelial growth factor (VEGF), endothelin-1, tissue factor, E-selectin, thrombomodulin, and proinflammatory cytokines, such as interleukin (IL)-1 $\alpha$, IL- 6 , and tumor necrosis factor- $\alpha$.).[30, 32-35]

\section{SRAGE}

The interaction of AGEs-RAGE results in oxidative damage and the production of matrix metalloproteinases (MMPs), whereby cell-bound RAGE is cleaved to produce soluble RAGE (sRAGE). [36] sRAGE competes with RAGE for RAGE ligands (AGEs, HMGB1, S100b) through binding or trapping, thus reducing inflammation mediated by RAGE. [36, 37] Studies have shown that RAGE signaling pathway is blocked by sRAGE, suggesting sRAGE as a potential therapeutic agent for preventing atherosclerosis.[38] To support this idea, the decrease in plasma sRAGE concentrations is a predictor of cardiovascular events and it is speculated that SRAGE may be a potential protective agent against vascular complications [39]

\section{AGES AND DIABETES}

AGEs are considered to be the main cause of different diabetic complications .[40] AGEs accumulate in most sites of diabetic complications including atherosclerotic plaque, kidney, and retina. [41]

\section{AGES and Diabetic Nephropathy}

Diabetic nephropathy is characterized by the accumulation of ECM (extracellular matrix) proteins 
in the glomerular mesangium and tubulointerstitium. AGEs may induce imbalances in the metabolism of ECM components, resulting in increased accumulation of collagen, fibronectin, and laminin.[42] After AGE modification, theaffinityoftypeIV collagenand heparan sulfate proteoglycans with laminin and fibronectin decreases. [43] The saccharification reaction inhibited the process of polymer self-assembly for collagen type IV and laminin .[44] Studies have shown that AGEs can stimulate angiotensin II (Ang II) type 1 receptor (AT1R) and induce DNA damage and partial detachment of podocyte.[45] These changes may be particularly pronounced in the glomerular basement membrane, where the induction of chemical crosslinking between amines leads to increased protein permeability .[46] In cultured human mesangial cells, it has been demonstrated that soluble AGE containing carboxymethyllysine induces the upregulation of CTGF (connective tissue growth factor; also known as IGFBP-2) and fibronectin,[47] which may promote the occurrence of renal fibrosis .[48]

\section{AGEs and Diabetic Peripheral Neuropathy}

RAGE is expressed in endothelial cells and Schwann cells of the perimysial and endoneurial vessels in rat peripheral nerves. A study showed that AGEs could cause death of neuronal cells and Schwann cells in vitro, resulting in changes in the structure and function of peripheral nerves.[49] In addition, neurofilaments and tubulin are modified by AGEs, which may interfere with axonal transport [50] and lead to the development of atrophy and degeneration of nerve fibers. AGEsmodified P0 protein may induce demyelination of nerve fibers .[51] Moreover, glycosylation of collagen and laminin alters the charge of basement membrane and leads to an increase in the permeability of blood vessels and thickening of the basement membrane. It has also been reported that AGEs can quench the vasodilatory mediator nitric oxide (NO)[52] and inhibit the expression of NO synthase [53]. thereby reducing neuronal blood flow and inducing hypoxia in peripheral nerves. Furthermore, the interaction between AGEs and RAGE on the endothelial cells of the peripheral and intimal blood vessels promotes the development of peripheral neuropathy.[54]

\section{AGES and Diabetic Retinopathy, Cataract}

AGEs lead to various retinal cell dysfunction and death. [55] Some studies have shown that the accumulation of AGEs is associated with dysfunction of glial cells in rat diabetic retinal Müller cells. [56] RAGE upregulates the pro-inflammatory response of retinal Müller glial cells. [57] AGEs can induce increased expression of ICAM-1 (intercellular adhesion molecule-1) in cultured bovine retinal endothelial cells and promote the reduction of diabetic retinal microvascular leukocytes .[58, 59] Studies have shown an increase in AGEs formation in the vitreous in patients with diabetic retinopathy. AGEs induce the expression of VEGF (basic fibroblast growth factor) gene in retinal cells by stimulating IL-6 secretion in human retinal Müller cells, inducing local hypoxia and increasing reactive oxygen species.[60] [61] This leads to increased mitogen and increased vascular endothelial growth factor (VEGF), which in turn stimulates neovascularization and induces proliferative retinopathy .[62] Local increases in VEGF concentrations are associated with increased vascular permeability .[63] In addition, recent studies have shown that AGEs are key regulators of non-proliferative retinopathy in patients with type 2 diabetes mellitus.[64] Therefore, AGEs are involved in the development of diabetic retinopathy.

The severity of diabetic cataracts is related to the rate of AGEs accumulation. Long-term hyperglycemia leads to progressive saccharification oxidation of lens proteins. The accumulation and cross-linking of AGEs with external capsules gradually nucleizes the lens and increases the thickness and stiffness, promoting the formation and development of cataracts. In the lens, AGEs induce the aggregation of lens proteins, forming high-molecular-weight aggregates that cause vision loss and astigmatism.[65] AGEs can also change the surface charge of proteins, resulting a conformational change that may subsequently affect the proteinwater interaction and reduce the transparency of the lens .[66, 67] Saccharification of lens proteins may be induced by elevated levels of glucose in the aqueous humor, resulting in increased production of AGEs and superoxide radicals. [11] AGE-RAGE in the lens epithelium further increases the production of 02- and H202.[68] In diabetic patients, reduced antioxidation capacity of the lens leads to increased level of free radicals and the sensitivity to oxidative stress .[69]

\section{AGES and Diabetic Cardiomyopathy}

Mitochondrial membrane depolarization is associated with AGE-induced cardiomyocyte dysfunction. [70] AGEs increase the cross-linking of matrix proteins such as collagen, laminin, vitronectin, and elastin .[71] As a 
result, matrix proteins have reduced pliable properties and become stiffer, which lead to decreased cardiac contractility and diastolic dysfunction. Increased cross-linking of collagen and elastin also leads to more ECM surface area, resulting in stiffer vasculature. $[19,72]$ Another pathway for diastolic dysfunction is activation of RAGE through AGEs .[73] In transgenic mouse models, overexpression of human RAGE in the heart was found to reduce contractile and diastolic intracellular calcium concentrations .[74] AGEs may also promote the development of heart failure .[75]

\section{AGEs and Diabetes Proinflammatory State}

AGEs have high affinity to cysteine in lysozyme and lactoferrin molecules, thereby reducing their antibacterial activity, which potentially contributes to the fact that the diabetic patients have declined antiinfectious abilities.[76] AGE-RAGE interaction inhibits phosphatidylinositol 3 (PI3) kinase activity, increases protein kinase C (PKC) activity and proinflammatory cytokine levels, and promotes diabetes mellitus inflammation state [77]

\section{AGEs and Diabetic Macroangiopathy}

Alarge number of clinical studies have shown that AGEs are closely related to diabetic macroangiopathy. AGEs can impaire endothelial cell function and accelerate the progression of atherosclerosis.[78] AGEs reduce the release of vasoactive substances (such as NO, SDF-1, PGI2, tPA, etc.), promote apoptosis of late endothelial progenitor cells (EPCs) and inhibit their migration and adhesion .[79] Accumulated AGEs also accelerate atherosclerosis by cross-linking endothelial matrix proteins leading to platelet aggregation and abnormal metabolism of lipoproteins .[80-82] Therefore, AGEs may be one of the pathological mechanisms of diabetic macrovascular complications.

\section{AGEs and Diabetic Bone Metabolism Abnormalities}

Patients with poorly controlled diabetes have increased AGE-modified collagen, affecting osteoblast differentiation and function in vitro, and leading to osteopenia [83] Through the NF- $\kappa \beta$ non-dependent mechanism, AGEs promote the apoptosis of human osteoblasts and mesenchymal stem cells, which further reduces bone formation.

\section{Hypoglycemic DRugs ANd Ages}

Hypoglycemic agents can be broadly classified into oral hypoglycemic agents and injectable hypoglycemic agents.[92] Current oral hypoglycemic drugs commonly used in China include insulin secretagogues, metformin, $\alpha$-glycosidase inhibitors, thiazolidinedione derivatives, dipeptidyl peptidase 4 (DPP-4) enzyme inhibitors, and sodium-glucose cotransporter-2 (SGLT-2) inhibitors and the like. Among these drugs the insulin secretagogues are further classified into sulfonylureas and non-sulfoureas (glinides). Injectable antidiabetic drugs include insulin and similar drugs, and glucagon-like peptide-1 (GLP-1) receptor agonists. They have different effects on AGEs in many ways.

\section{a-Glucosidase Inhibitors}

In diabetic animals, since acarbose reduces the mean blood glucose area under the curve, the nonenzymatically saccharified protein and the formation of AGEs are reduced. [84, 85] Patients with type 2 diabetes treated with acarbose have reduced serum levels of glyceraldehyde-derived AGEs.[86] Acarbose treatment can significantly reduce the level of some inflammatory factors that are present in higher levels in diabetes patients than healthy individuals including AGEs.[87] In addition, acarbose has been shown to inhibit the formation of aortic collagen glycosylation in diabetic rats.[88]

\section{Glinides}

Glyceraldehyde reacts rapidly with the amino groups of proteins to form glyceraldehyde-derived AGEs, causing vascular inflammation and endothelial dysfunction, and accelerating the atherosclerotic process in diabetic patients. Studies have found that nateglinide reduces glyceraldehyde-derived AGE levels in GK (Goto-Kakizaki) rats after 6 weeks of treatment. [89]

In ZF (Zucker fat) rats, an animal model of insulin resistance and obesity, studies have shown that combination therapy of nateglinide (NAT) and telmisartan (TEL) improves postprandial metabolic disturbances and mitigate insulin resistance, with reduced AGEs levels in serum, RAGE expression levels, and AGE-RAGE index, probably due to the suppression of the AGE-RAGE signal in the liver.[90]

\section{Thiazolidinedione Insulin Sensitizer}

Since thiazolidinediones have PPAR $\gamma$ agonist activity, they have been shown to play a role in anti-AGE therapy by upregulating sRAGE expression and being inversely related to atherosclerosis.[91] Circulating 
soluble RAGE (sRAGE) and endocrine RAGE (eRAGE) compete with RAGE to bind AGEs. Binding of AGEs to their receptors (RAGE) results in the production of oxygen free radicals, nuclear factor kappa-beta, pro-inflammatory cytokines, and cell adhesion molecules that are involved in the pathophysiological process of triggering cardiovascular disease (CVD). Rosiglitazone has been used to increase sRAGE levels. [92] A randomized placebo-controlled study of 111 patients with type 2 diabetes and high-risk coronary heart disease who had undergone rosiglitazone in the year of 2013[93] tested increased levels of sRAGE after 6 months of rosiglitazone treatment. The PPAR $\gamma$ agonist rosiglitazone can reduce AGE levels, improve arterial injury [94] , and mitigate AGEs-induced EPCs dysfunction.[95] In human neural stem cells (hNSCs) exposed to AGEs, two neuroprotective factors (Bcl-2 and PGC1 $\alpha$ ) are down-regulated, and inflammatory response factors (TNF- $\alpha$ and IL-1 $\beta$ ), NF- $\kappa B$ (p65) and inflammatory genes (iNOS and COX-2) are upregulated. Aosiglitazone can rescue these effects in hNSCs via activation of PPAR $\gamma$ and inhibits the activity of caspase 3, thereby increases the viability of hNSC. This neuroprotective effect of rosiglitazone can be effectively blocked by a PPAR $\gamma$-specific antagonist (GW9662), indicating that the above-mentioned effects of rosiglitazone are mediated by the PPAR $\gamma$ dependent pathway.[96]

A study conducted in 2010[97] showed that pioglitazone significantly increased sRAGE levels in diabetic patients at 12 weeks of follow-up. In the 24-week follow-up period of PioRAGE [98] trial, pioglitazone inhibited RAGE expression and increased plasma sRAGE levels, independent of plasma glucose or insulin resistance levels. In patients with type 2 diabetes, pioglitazone treatment has a good overall efficacy by significantly affecting the level of serum adiponectin, AGEs, human normal T cells, and secreted factors RANTES, endothelin ET, and homocysteine Hcy.[99]

\section{Sulfonylureas Secretagogues}

One of the sulfonylurea derivatives, GP, inhibits ATPdependent $\mathrm{K}+$ channels therefore can completely reverse the inhibitory effects of AGEs on ATP production and insulin secretion.[100]

Gliclazide can reduce the expression of RAGE mRNA, which may have a protective effect on renal tissue damage in diabetic rats.[101] AGEs promote the binding of NF- $\mathrm{KB}$ to the motif at the VEGF promoter region in the bovine retinal capillary endothelial cells (BRECs), leading to the proliferation of these cells. Gliclazide blocks AGE-induced DNA binding activity of NF- $\kappa B$ and inhibits AGE-induced VEGF expression and PKC activation. Treatment with anti-VEGF antibodies or gliclazide inhibited the above-mentioned cell proliferation effects.[102]

AGEs significantly inhibited the expression of megalin and cubic protein, cubulin, and the uptake of albumin by HK-2 cells in vitro. In glomerular cells of GK rats, Gliconeone can inhibit the expression of RAGE and PKC- $\beta$, upregulate the expression of PKA, megalin and cubilin, promote the secretion of C-peptide, and increase the albumin uptake. Treatment with gliquidone alleviated the injury of glomerular basement membrane and podocytes, promoted renal tubular reabsorption, and effectively reduced urinary protein and proteinuria in diabetic nephropathy GK rats.[103] [104] Gliquidone also inhibited AGEsinduced expression and secretion of RANTE (regulated on activation, normal $\mathrm{T}$ cell expressed and secreted) in human mesangial cell (HRMC).[105]

Glimepiride may reduce toxic glyceraldehyde-derived AGEs (glycerol-AGEs) levels and increase colonystimulating factors to potentially repair tissue damage [106]

\section{Metformin}

MG (methylglyoxal) is the major precursor of AGE and is directly toxic to tissues. Metformin binds MG and inactivates it, reducing MG-related AGEs.[107] Metformin inhibits the production and accumulation of AGEs, thereby inhibiting the development of adverse myocardial structural and functional changes.[108] AGEs-induced proliferation of VSMCs was inhibited by metformin. $[109,110]$ Thiazolidine-derived metformin reduces AGE levels in patients with polycystic ovary syndrome and reduces arteriosclerosis in young women with polycystic ovary syndrome.[111]

Metformin can reduce the accumulation of AGEs and down-regulate the expression of RAGE in the kidney of diabetic rats.[112] Metformin inhibited AGEs-induced growth of SW-480 cells.[113] Metformin reduced the serum AGEs level in postmenopausal osteoporosis rats, which in turn improves bone metabolism.[114]

\section{Dipeptidyl Peptidase-4 Inhibitor}

Sitagliptin reduced the levels of RAGE and angiotensin II type 1 receptors in spontaneously hypertensive rats. 
Hypoglycemic Drugs and Advanced Glycation Endproducts

[115] Sitagliptin significantly inhibited AGEs-induced viability of mesangial cells and downregulated the level of collagen IV (Col IV) in the supernatant, which may exert renal protective effects by causing autophagy of mesangial cells.[116]

In $\mathrm{db} / \mathrm{db}$ mice, cilizytin can downregulate serum AGEs, inhibit glycosylation in vivo and in cells cultured in vitro, and alleviate AGE-related diabetic complications. [117] Treatment with vildagliptin can downregulate the levels of AGEs, RAGE and oxidative stress marker 8-OHdG (8-hydroxydeoxyguanosine) in thoracic aorta of diabetic rats, and the above-mentioned increase in levels of substances with MCP-1 (mononuclear) Cell chemokine-1), VCAM-1, and PAI-1 (type I plasminogen activator inhibitor) gene expression were associated with decreased expression. [118] Linagliptin significantly inhibited AGE-induced ROS production and downregulated the expression of RAGE, ICAM-1 and PAI-1 genes in HUVEC cells[119], and reduced AGEs, RAGE gene expression, and 8-OHdG levels in the kidneys of diabetic rats.[120] Another study found that alogliptin can block the AGEs-RAGE axis in patients with type 2 diabetes, thereby reducing proteinuria.[121]

\section{GLP-1 Receptor Agonist}

GLP-1 inhibits AGEs-induced RAGE gene expression, protein arginine methyltransferase-1 (PRMT-1) gene expression and ROS production. [122] In addition, GLP-1 binds to RAGE and inhibits RAGE activation. [123] GLP-1 is also reported to inhibit AGEs-induced apoptosis of EC cells, increase the ratio of antiapoptosis Bcl-2/pro-apotosis Bax, downregulate cytochrome $\mathrm{C}$ levels, and inhibit caspase-3 and caspase-9 activities.[124] Moreover, recent studies have shown that GLP-1 can directly act on GLP-1R of ECs, which may play a role in anti-AGEs by reducing RAGE expression.[125] GLP-1 can reduce the levels of RAGE, ICAM-1 (intercellular adhesion molecule-1) and VCAM-1 (vascular cell adhesion molecule-1) in human retinal pigment epithelial cells.[126] Continuous intraperitoneal injection of the GLP-1 analogue exendin-4 inhibits renal RAGE gene expression. [122] In rat mesangial cells RMC, PPAR $\delta$ and GLP-1 receptor agonists significantly inhibited AGE-induced production of IL- 6 and TNF- $\alpha$, down-regulated AGEinduced RAGE expression, and decreased mesangial cell death.[127] Liraglutide reduced aortic RAGE expression and atherosclerosis in a diabetic ApoE-/mouse model.[128, 129]

\section{Sodium-Glucose Cotransporter-2 (SGLT-2)} Inhibitors

Treatment with SGLT-2 inhibitors downregulates increased AGE / RAGE signaling in ZDF rats (Zucker diabetic rats), animal models for type 2 diabetes. Serum level of AGE precursor methylglyoxal is reduced, thereby reducing AGE formation and RAGEdependent signal transduction. In ZDF rats, treatment with engliflozin can prevent oxidative stress, AGE/ RAGE signaling, and inflammation development by reducing glucose levels, restoring insulin sensitivity and signal transduction, increasing glucose utilization, and partially improving endothelial function. In addition, improvement of the redox state contributes to decreased apoptosis of beta cells and increased insulin production. [130] Treatment with high-dose SGLT2 inhibitors in STZ rats reduced both transcription and translation of RAGE gene, AGE-positive protein levels in the aorta, and serum level of AGE precursor methylglyoxal.[131] Furthermore, studies have shown that application of engliflozin for 4 weeks significantly reduced the expression of AGEs, RAGE, 8-OHdG, and F4/80 in kidneys of streptozotocin-induced diabetic rats. This suppression of AGE-RAGE axis partly inhibited the oxidation, inflammation and fibrosis in the kidneys of diabetic rats.[132]

\section{Insulin}

Studies have confirmed that circulating levels of AGEs are associated with insulin resistance, indicating an association of RAGE gene polymorphisms and insulin resistance.[133] In addition, glycated albumin (a source of AGEs) may be involved in the regulation of insulin signaling. In adipose tissue of insulin-resistant rat models, an increase in methylglyoxal (a precursor of AGEs) impairs insulin signaling by reducing insulininduced glucose uptake[134]. AGEs are involved in several mechanisms to contribute to insulin resistance. First, due to direct changes in insulin, glucose uptake is reduced; insulin clearance is suppressed; and insulin secretion is further increased. Second, AGE may increase RAGE expression and promote insulin resistance by decreasing the expression of AGER1 and an insulin receptor substrate-SIRT1-whose depletion leads to changes in insulin signaling and induction of inflammation. Third, AGEs affect insulin signaling and induce inflammation by stimulating PKC $\alpha$ and upregulating TNF $\alpha$ [135-141] 
Hypoglycemic Drugs and Advanced Glycation Endproducts

\section{CONCLUSION AND FUTURE EXPECTATIONS}

Diabetes is a common chronic disease that severely affects human health. AGEs promote the occurrence and development of diabetes and its complications through multiple mechanisms that involve many signaling pathways. In recent years, research on AGEs has become one of the hot spots. But research in this area is relatively few and not deep enough. Various hypoglycemic drugs, in addition to their role in in hypoglycemia, hindered the production and accumulation of AGEs from many aspects,such as:Acarbose, Nateglinide, Glimepiride can reduce glycerol-AGEs levels;increased MG (methylglyoxal, the major precursor of AGE) interferes with insulin signaling; SGLT-2 inhibitors reduce MG levels; Metformin binds MG, resulting in decreased production of MG-associated AGEs;Gliclazide, Metformin, Linagliptin, GLP-1 receptor agonists, and Engliflozin can all reduce the expression of AGEsRAGE genes in kidney tissues of diabetic rats, and so on.Thereby hypoglycemic drugs reduce the adverse effects of AGEs on various tissues. This review may provide rationale for the research and development of specific drugs targeting AGEs in the future.

\section{REFERENCE}

1 Group IDFDA (2015) Update of mortality attributable to diabetes for the IDF Diabetes Atlas: Estimates for the year 2013. Diabetes Res Clin Pract 109 (3): 461-465 DOI 10.1016/j. diabres.2015.05.037

$2 \mathrm{Hu}$ C, Jia W (2018) Diabetes in China: Epidemiology and Genetic Risk Factors and Their Clinical Utility in Personalized Medication. Diabetes 67 (1): 3-11 DOI 10.2337/dbi17-0013

3 Miyata T, van Ypersele de Strihou C, Kurokawa K, Baynes JW (1999) Alterations in nonenzymatic biochemistry in uremia: origin and significance of "carbonyl stress" in long-term uremic complications. Kidney Int 55 (2): 389-399 DOI 10.1046/j.1523-1755.1999.00302.x

4 Brownlee M (1991) Glycosylation products as toxic mediators of diabetic complications. Annu Rev Med 42: 159-166 DOI 10.1146/annurev. me.42.020191.001111

5 Cai W, He JC, Zhu L, Peppa M, Lu C, Uribarri J, Vlassara H (2004) High levels of dietary advanced glycation end products transform low- density lipoprotein into a potent redox-sensitive mitogen-activated protein kinase stimulant in diabetic patients. Circulation 110 (3): 285-291 DOI 10.1161/01.cir.0000135587.92455.0d

6 Dukic-Stefanovic S, Schinzel R, Riederer P, Munch G (2001) AGES in brain ageing: AGE-inhibitors as neuroprotective and anti-dementia drugs? Biogerontology 2 (1): 19-34

7 Lyons TJ, Silvestri G, Dunn JA, Dyer DG, Baynes JW (1991) Role of glycation in modification of lens crystallins in diabetic and nondiabetic senile cataracts. Diabetes 40 (8): 1010-1015

8 Forbes JM, Yee LT, Thallas V, Lassila M, Candido R, Jandeleit-Dahm KA, Thomas MC, Burns WC, Deemer EK, Thorpe SR, Cooper ME, Allen TJ (2004) Advanced glycation end product interventions reduce diabetes-accelerated atherosclerosis. Diabetes 53 (7): 1813-1823

9 Ahmed N (2005) Advanced glycation endproducts--role in pathology of diabetic complications. Diabetes Res Clin Pract 67 (1): 3-21 DOI 10.1016/j.diabres.2004.09.004

10 Yamamoto Y, Doi T, Kato I, Shinohara H, Sakurai S, Yonekura H, Watanabe T, Myint KM, Harashima A, Takeuchi M, Takasawa S, Okamoto H, Hashimoto N, Asano M, Yamamoto H (2005) Receptor for advanced glycation end products is a promising target of diabetic nephropathy. Ann N Y Acad Sci 1043: 562-566 DOI 10.1196/annals.1333.064

11 Stitt AW (2005) The maillard reaction in eye diseases. Ann N Y Acad Sci 1043: 582-597 DOI 10.1196/annals.1338.066

12 Jono T, Kimura T, Takamatsu J, Nagai R, Miyazaki K, Yuzuriha T, Kitamura T, Horiuchi S (2002) Accumulation of imidazolone, pentosidine and N(epsilon)-(carboxymethyl)lysine in hippocampal CA4 pyramidal neurons of aged human brain. Pathol Int 52 (9): 563-571

13 Zhu Y, Shu T, Lin Y, Wang H, Yang J, Shi Y, Han X (2011) Inhibition of the receptor for advanced glycation endproducts (RAGE) protectspancreatic beta-cells. Biochem Biophys Res Commun 404 (1): 159-165 DOI 10.1016/j.bbrc.2010.11.085

14 Yamagishi S, Matsui T (2010) Advanced glycation end products, oxidative stress and diabetic nephropathy. Oxid Med Cell Longev 3 (2): 101108 DOI 10.4161/oxim.3.2.11148 
Hypoglycemic Drugs and Advanced Glycation Endproducts

15 Nam MH, Son WR, Lee YS, Lee KW (2015) Glycolaldehyde-derived advanced glycation end products (glycol-AGEs)-induced vascular smooth muscle cell dysfunction is regulated by the AGES-receptor (RAGE) axis in endothelium. Cell Commun Adhes 22 (2-6): 67-78 DOI $10.1080 / 15419061.2016 .1225196$

16 Holm T, Raghavan CT, Nahomi R, Nagaraj RH, Kessel L (2015) Effects of photobleaching on selected advanced glycation end products in the human lens. BMC Res Notes 8: 5 DOI 10.1186/ s13104-015-0977-3

17 Saulnier PJ, Wheelock KM, Howell S, Weil EJ, Tanamas SK, Knowler WC, Lemley KV, Mauer M, Yee B, Nelson RG, Beisswenger PJ (2016) Advanced Glycation End Products Predict Loss of Renal Function and Correlate With Lesions of Diabetic Kidney Disease in American Indians With Type 2 Diabetes. Diabetes 65 (12): 37443753 DOI $10.2337 / \mathrm{db} 16-0310$

18 Zieman SJ, Kass DA (2004) Advanced glycation endproduct crosslinking in the cardiovascular system: potential therapeutic target for cardiovascular disease. Drugs 64 (5): 459-470

19 Brownlee M (1995) Advanced protein glycosylation in diabetes and aging. Annu Rev Med 46: 223-234 DOI 10.1146/annurev. med.46.1.223

20 Paul RG, Bailey AJ (1999) The effect of advanced glycation end-product formation upon cellmatrix interactions. Int J Biochem Cell Biol 31 (6): 653-660

21 Corman B, Duriez M, Poitevin P, Heudes D, Bruneval P, Tedgui A, Levy BI (1998) Aminoguanidine prevents age-related arterial stiffening and cardiac hypertrophy. Proc Natl Acad Sci U S A 95 (3): 1301-1306

22 Sobal G, Menzel EJ, Sinzinger H (2001) Calcium antagonists as inhibitors of in vitro low density lipoprotein oxidation and glycation. Biochem Pharmacol 61 (3): 373-379

23 Bidasee KR, Nallani K, Yu Y, Cocklin RR, Zhang Y, Wang M, Dincer UD, Besch HR, Jr. (2003) Chronic diabetes increases advanced glycation end products on cardiac ryanodine receptors/ calcium-release channels. Diabetes 52 (7): 18251836
24 Bidasee KR, Zhang Y, Shao CH, Wang M, Patel KP, Dincer UD, Besch HR, Jr. (2004) Diabetes increases formation of advanced glycation end products on Sarco(endo) plasmic reticulum Ca2+ATPase. Diabetes 53 (2): 463-473

25 Lagadic-Gossmann D, Buckler KJ, Le Prigent K, Feuvray D (1996) Altered Ca2+ handling in ventricular myocytes isolated from diabetic rats. Am J Physiol 270 (5 Pt 2): H1529-1537 DOI 10.1152/ajpheart.1996.270.5.H1529

26 Bidasee KR, Nallani K, Henry B, Dincer UD, Besch HR, Jr. (2003) Chronic diabetes alters function and expression of ryanodine receptor calciumrelease channels in rat hearts. Mol Cell Biochem 249 (1-2): 113-123

27 Neeper M, Schmidt AM, Brett J, Yan SD, Wang F, Pan YC, Elliston K, Stern D, Shaw A (1992) Cloning and expression of a cell surface receptor for advanced glycosylation end products of proteins. J Biol Chem 267 (21): 14998-15004

28 Li J, Schmidt AM (1997) Characterization and functional analysis of the promoter of RAGE, the receptor for advanced glycation end products. J Biol Chem 272 (26): 16498-16506

29 Schmidt AM, Hori O, Brett J, Yan SD, Wautier JL, Stern D (1994) Cellular receptors for advanced glycation end products. Implications for induction of oxidant stress and cellular dysfunction in the pathogenesis of vascular lesions. Arterioscler Thromb 14 (10): 1521-1528

30 Yan SD, Schmidt AM, Anderson GM, Zhang J, Brett J, Zou YS, Pinsky D, Stern D (1994) Enhanced cellular oxidant stress by the interaction of advanced glycation end products with their receptors/binding proteins. J Biol Chem 269 (13): 9889-9897

31 Evans JL, Goldfine ID, Maddux BA, Grodsky GM (2002) Oxidative stress and stress-activated signaling pathways: a unifying hypothesis of type 2 diabetes. Endocr Rev 23 (5): 599-622 DOI 10.1210/er.2001-0039

32 Huttunen HJ, Fages C, Rauvala H (1999) Receptor for advanced glycation end products (RAGE)mediated neurite outgrowth and activation of NF-kappaB require the cytoplasmic domain of the receptor but different downstream signaling pathways. J Biol Chem 274 (28): 19919-19924 
Hypoglycemic Drugs and Advanced Glycation Endproducts

33 Neumann A, Schinzel R, Palm D, Riederer P, Munch G (1999) High molecular weight hyaluronic acid inhibits advanced glycation endproduct-induced NF-kappaB activation and cytokine expression. FEBS Lett 453 (3): 283-287

34 Basta G, Schmidt AM, De Caterina R (2004) Advanced glycation end products and vascular inflammation: implications for accelerated atherosclerosis in diabetes. Cardiovasc Res 63 (4): 582-592 DOI 10.1016/j.cardiores.2004.05.001

35 Basta G, Lazzerini G, Massaro M, Simoncini T, Tanganelli P, Fu C, Kislinger T, Stern DM, Schmidt AM, De Caterina R (2002) Advanced glycation end products activate endothelium through signal-transduction receptor RAGE: a mechanism for amplification of inflammatory responses. Circulation 105 (7): 816-822

36 Prasad K (2014) Low levels of serum soluble receptors for advanced glycation end products, biomarkers for disease state: myth or reality. Int J Angiol 23 (1): 11-16 DOI 10.1055/s-00331363423

37 Selejan SR, Poss J, Hewera L, Kazakov A, Bohm M, Link A (2012) Role of receptor for advanced glycation end products in cardiogenic shock. Crit Care Med 40 (5): 1513-1522 DOI 10.1097/ CCM.0b013e318241e536

38 Ha CH, Kim S, Chung J, An SH, Park S, Choi D, Kwon K (2013) Inhibitory effect of soluble RAGE in disturbed flow-induced atherogenesis. Int J Mol Med 32 (2): 373-380 DOI 10.3892/ ijmm.2013.1393

39 Chiang KH, Huang PH, Huang SS, Wu TC, Chen JW, Lin SJ (2009) Plasma levels of soluble receptor for advanced glycation end products are associated with endothelial function and predict cardiovascular events in nondiabetic patients. Coron Artery Dis 20 (4): 267-273 DOI 10.1097/ MCA.0b013e32832c459c

40 Negre-Salvayre A, Salvayre R, Auge N, Pamplona $R$, Portero-Otin M (2009) Hyperglycemia and glycation in diabetic complications. Antioxid Redox Signal 11 (12): 3071-3109 DOI 10.1089/ ars.2009.2484

41 Hammes HP, Alt A, Niwa T, Clausen JT, Bretzel RG, Brownlee M, Schleicher ED (1999) Differential accumulation of advanced glycation end products in the course of diabetic retinopathy. Diabetologia 42 (6): 728-736 DOI 10.1007/s001250051221

42 Forbes JM, Cooper ME, Oldfield MD, Thomas MC (2003) Role of advanced glycation end products in diabetic nephropathy. J Am Soc Nephrol 14 (8 Suppl 3): S254-258

43 Charonis AS, Tsilbary EC (1992) Structural and functional changes of laminin and type IV collagen after nonenzymatic glycation. Diabetes 41 Suppl 2: 49-51

44 Walton HA, Byrne J, Robinson GB (1992) Studies of the permeation properties of glomerular basement membrane: cross-linking renders glomerular basement membrane permeable to protein. Biochim Biophys Acta 1138 (3): 173183

45 Fukami K, Yamagishi S, Kaifu K, Matsui T, Kaida Y, Ueda S, Takeuchi M, Asanuma K, Okuda S (2013) Telmisartan inhibits AGE-induced podocyte damage and detachment. Microvasc Res 88: 7983 DOI 10.1016/j.mvr.2013.04.006

46 Kelly DJ, Gilbert RE, Cox AJ, Soulis T, Jerums G, Cooper ME (2001) Aminoguanidine ameliorates overexpression of prosclerotic growth factors and collagen deposition in experimental diabetic nephropathy. J Am Soc Nephrol 12 (10): 20982107

47 Twigg SM, Cao Z, SV MC, Burns WC, Brammar G, Forbes JM, Cooper ME (2002) Renal connective tissue growth factor induction in experimental diabetes is prevented by aminoguanidine. Endocrinology 143 (12): 4907-4915 DOI 10.1210/en.2002-220619

48 Riser BL, Denichilo M, Cortes P, Baker C, Grondin JM, Yee J, Narins RG (2000) Regulation of connective tissue growth factor activity in cultured rat mesangial cells and its expression in experimental diabetic glomerulosclerosis. J Am Soc Nephrol 11 (1): 25-38

49 Sekido H, Suzuki T, Jomori T, Takeuchi M, YabeNishimura C, Yagihashi S (2004) Reduced cell replication and induction of apoptosis by advanced glycation end products in rat Schwann cells. Biochem Biophys Res Commun 320 (1): 241-248 DOI 10.1016/j.bbrc.2004.05.159 
Hypoglycemic Drugs and Advanced Glycation Endproducts

50 Williams SK, Howarth NL, Devenny JJ, Bitensky MW (1982) Structural and functional consequences of increased tubulin glycosylation in diabetes mellitus. Proc Natl Acad Sci U S A 79 (21): 6546-6550

51 Vlassara H, Brownlee M, Cerami A (1981) Nonenzymatic glycosylation of peripheral nerve protein in diabetes mellitus. Proc Natl Acad Sci U S A 78 (8): 5190-5192

52 Bucala R, Tracey KJ, Cerami A (1991) Advanced glycosylation products quench nitric oxide and mediate defective endothelium-dependent vasodilatation in experimental diabetes. J Clin Invest 87 (2): 432-438 DOI 10.1172/jci115014

53 Amore A, Cirina P, Mitola S, Peruzzi L, Gianoglio B, Rabbone I, Sacchetti C, Cerutti F, Grillo C, Coppo R (1997) Nonenzymatically glycated albumin (Amadori adducts) enhances nitric oxide synthase activity and gene expression in endothelial cells. Kidney Int 51 (1): 27-35

54 Schmidt AM, Hasu M, Popov D, Zhang JH, Chen J, Yan SD, Brett J, Cao R, Kuwabara K, Costache G, et al. (1994) Receptor for advanced glycation end products (AGEs) has a central role in vessel wall interactions and gene activation in response to circulating AGE proteins. Proc Natl Acad Sci U S A 91 (19): 8807-8811

55 Stitt AW, Curtis TM (2011) Diabetes-related adduct formation and retinopathy. J Ocul Biol Dis Infor 4 (1-2): 10-18 DOI 10.1007/s12177-0119070-X

56 Curtis TM, Hamilton R, Yong PH, McVicar CM, Berner A, Pringle R, Uchida K, Nagai R, Brockbank S, Stitt AW (2011) Muller glial dysfunction during diabetic retinopathy in rats is linked to accumulation of advanced glycation end-products and advanced lipoxidation endproducts. Diabetologia 54 (3): 690-698 DOI 10.1007/s00125-010-1971-x

57 Zong H, Ward M, Madden A, Yong PH, Limb GA, Curtis TM, Stitt AW (2010) Hyperglycaemiainduced pro-inflammatory responses by retinal Muller glia are regulated by the receptor for advanced glycation end-products (RAGE). Diabetologia 53 (12): 2656-2666 DOI 10.1007/ s00125-010-1900-z
58 Moore TC, Moore JE, Kaji Y, Frizzell N, Usui T, Poulaki V, Campbell IL, Stitt AW, Gardiner TA, Archer DB, Adamis AP (2003) The role of advanced glycation end products in retinal microvascular leukostasis. Invest Ophthalmol Vis Sci 44 (10): 4457-4464

59 Mamputu JC, Renier G (2004) Advanced glycation end-products increase monocyte adhesion to retinal endothelial cells through vascular endothelial growth factor-induced ICAM-1 expression: inhibitory effect of antioxidants. J Leukoc Biol 75 (6): 1062-1069 DOI 10.1189/ jlb.0603265

60 Ai J, Liu Y, Sun JH (2013) Advanced glycation endproducts stimulate basic fibroblast growth factor expression in cultured Muller cells. Mol Med Rep 7 (1): 16-20 DOI 10.3892/mmr.2012.1152

61 Caldwell RB, Bartoli M, Behzadian MA, ElRemessy AE, Al-Shabrawey M, Platt DH, Caldwell RW (2003) Vascular endothelial growth factor and diabetic retinopathy: pathophysiological mechanisms and treatment perspectives. Diabetes Metab Res Rev 19 (6): 442-455 DOI 10.1002/dmrr.415

62 Nakamura N, Hasegawa G, Obayashi H, Yamazaki M, Ogata M, Nakano K, Yoshikawa T, Watanabe A, Kinoshita S, Fujinami A, Ohta M, Imamura Y, Ikeda $T$ (2003) Increased concentration of pentosidine, an advanced glycation end product, and interleukin- 6 in the vitreous of patients with proliferative diabetic retinopathy. Diabetes Res Clin Pract 61 (2): 93-101

63 Podesta F, Romeo G, Liu WH, Krajewski S, Reed JC, Gerhardinger C, Lorenzi M (2000) Bax is increased in the retina of diabetic subjects and is associated with pericyte apoptosis in vivo and in vitro. Am J Pathol 156 (3): 1025-1032 DOI 10.1016/s0002-9440(10)64970-x

64 Choudhuri S, Dutta D, Sen A, Chowdhury IH, Mitra B, Mondal LK, Saha A, Bhadhuri G, Bhattacharya B (2013) Role of N-epsilon- carboxy methyl lysine, advanced glycation end products and reactive oxygen species for the development of nonproliferative and proliferative retinopathy in type 2 diabetes mellitus. Mol Vis 19: 100-113 
Hypoglycemic Drugs and Advanced Glycation Endproducts

65 Nagaraj RH, Linetsky M, Stitt AW (2012) The pathogenic role of Maillard reaction in the aging eye. Amino Acids 42 (4): 1205-1220 DOI 10.1007/s00726-010-0778-x

66 Beswick HT, Harding JJ (1987) Conformational changes induced in lens alpha- and gammacrystallins by modification with glucose 6-phosphate. Implications for cataract. Biochem J 246 (3): 761-769

67 Kumar MS, Reddy PY, Kumar PA, Surolia I, Reddy GB (2004) Effect of dicarbonyl-induced browning on alpha-crystallin chaperone-like activity: physiological significance and caveats of in vitro aggregation assays. Biochem 379 (Pt 2): 273-282 DOI 10.1042/bj20031633

68 Gul A, Rahman MA, Hasnain SN, Salim A, Simjee SU (2008) Could oxidative stress associate with age products in cataractogenesis? Curr Eye Res 33 (8): 669-675 DOI 10.1080/02713680802250939

69 Ookawara T, Kawamura N, Kitagawa Y, Taniguchi N (1992) Site-specific and random fragmentation of Cu,Zn-superoxide dismutase by glycation reaction. Implication of reactive oxygen species. J Biol Chem 267 (26): 18505-18510

70 Ma H, Li SY, Xu P, Babcock SA, Dolence EK, Brownlee M, Li J, Ren J (2009) Advanced glycation endproduct (AGE) accumulation and AGE receptor (RAGE) up-regulation contribute to the onset of diabetic cardiomyopathy. J Cell Mol Med 13 (8B): 1751-1764 DOI 10.1111/j.15824934.2008.00547.x

71 Smit AJ, Lutgers HL (2004) The clinical relevance of advanced glycation endproducts (AGE) and recent developments in pharmaceutics to reduce AGE accumulation. Curr Med Chem 11 (20): 2767-2784

72 Kass DA, Shapiro EP, Kawaguchi M, Capriotti AR, Scuteri A, deGroof RC, Lakatta EG (2001) Improved arterial compliance by a novel advanced glycation end-product crosslink breaker. Circulation 104 (13): 1464-1470

73 Brett J, Schmidt AM, Yan SD, Zou YS, Weidman E, Pinsky D, Nowygrod R, Neeper M, Przysiecki C, Shaw A, et al. (1993) Survey of the distribution of a newly characterized receptor for advanced glycation end products in tissues. Am J Pathol 143 (6): 1699-1712
74 Petrova R, Yamamoto Y, Muraki K, Yonekura H, Sakurai S, Watanabe T, Li H, Takeuchi M, Makita Z, Kato I, Takasawa S, Okamoto H, Imaizumi Y, Yamamoto H (2002) Advanced glycation endproduct-induced calcium handling impairment in mouse cardiac myocytes. J Mol Cell Cardiol 34 (10): 1425-1431

75 Bodiga VL, Eda SR, Bodiga S (2014) Advanced glycation end products: role in pathology of diabetic cardiomyopathy. Heart Fail Rev 19 (1): 49-63 DOI 10.1007/s10741-013-9374-y

76 Singh VP, Bali A, Singh N, Jaggi AS (2014) Advanced glycation end products and diabetic complications. Korean J Physiol Pharmacol 18 (1): 1-14 DOI 10.4196/kjpp.2014.18.1.1

77 Mascarenhas JV, Jude EB (2014) The Charcot foot as a complication of diabetic neuropathy. Curr Diab Rep 14 (12): 561 DOI 10.1007/s11892014-0561-6

$78 \mathrm{Xu} \mathrm{B}$, Chibber R, Ruggiero D, Kohner E, Ritter J, Ferro A (2003) Impairment of vascular endothelial nitric oxide synthase activity by advanced glycation end products. FASEB J 17 (10): 1289-1291 DOI 10.1096/fj.02-0490fje

79 Li H, Zhang X, Guan X, Cui X, Wang Y, Chu H, Cheng $M$ (2012) Advanced glycation end products impair the migration, adhesion and secretion potentials of late endothelial progenitor cells. Cardiovasc Diabetol 11: 46 DOI 10.1186/14752840-11-46

80 Makita Z, Vlassara H, Cerami A, Bucala R (1992) Immunochemical detection of advanced glycosylation end products in vivo. J Biol Chem 267 (8): 5133-5138

81 Vlassara H (1997) Recent progress in advanced glycation end products and diabetic complications. Diabetes 46 Suppl 2: S19-25

82 Bierhaus A, Hofmann MA, Ziegler R, Nawroth PP (1998) AGEs and their interaction with AGE-receptors in vascular disease and diabetes mellitus. I. The AGE concept. Cardiovasc Res 37 (3): 586-600

83 Katayama Y, Akatsu T, Yamamoto M, Kugai N, Nagata N (1996) Role of nonenzymatic glycosylation of type I collagen in diabetic osteopenia. J Bone Miner Res 11 (7): 931-937 DOI 10.1002/jbmr.5650110709 
Hypoglycemic Drugs and Advanced Glycation Endproducts

84 Bischoff H (1995) The mechanism of alphaglucosidase inhibition in the management of diabetes. Clin Invest Med 18 (4): 303-311

85 Bischoff H (1994) Pharmacology of alphaglucosidase inhibition. Eur J Clin Invest 24 Suppl 3: $3-10$

86 Tsunosue M, Mashiko N, Ohta Y, Matsuo Y, Ueda K, Ninomiya M, Tanaka S, Hoshiko M, Yoshiyama Y, Takeuchi M, Ueda S, Yamagishi S (2010) An alpha-glucosidase inhibitor, acarbose treatment decreases serum levels of glyceraldehydederived advanced glycation end products (AGEs) in patients with type 2 diabetes. Clin Exp Med 10 (2): 139-141 DOI 10.1007/s10238-009-0074-9

87 刘海霞，孙李永隽，刘奔，刘丹丹，李晶，张 萍，王荔，刘佳，王黎，孟秀香（2011）阿卡波 糖对2型糖尿病患者慢性炎症相矢因子水平的影 响. 中华内分泌代谢杂志 27 (3)：193-198

88 金晖，刘乃丰（2001）阿卡波糖对糖尿病大鼠 主动脉胶原蛋白糖基化的影响. 中国病理生理 杂志 17 (10)：951-953

89 Kitahara Y, Takeuchi M, Miura K, Mine T, Matsui T, Yamagishi S (2008) Glyceraldehyde-derived advanced glycation end products (AGEs). A novel biomarker of postprandial hyperglycaemia in diabetic rats. Clin Exp Med 8 (3): 175-177 DOI 10.1007/s10238-008-0176-9

90 Miura K, Kitahara Y, Kajioka T, Takeuchi M, Yamagishi S (2011) Combination Therapy with Nateglinide and Telmisartan Ameliorates Insulin Resistance in Zucker Fatty Rats by Suppressing Advanced Glycation End Product Receptor Axis. Horm Metab Res 43 (3): e1 DOI 10.1055/s-00301268483

91 Nenna A, Nappi F, Avtaar Singh SS, Sutherland FW, Di Domenico F, Chello M, Spadaccio C (2015) Pharmacologic Approaches Against Advanced Glycation End Products (AGEs) in Diabetic Cardiovascular Disease. Res Cardiovasc Med 4 (2): e26949 DOI 10.5812/ cardiovascmed.4(2)2015.26949

92 Prasad K, Tiwari S (2017) Therapeutic Interventions for Advanced GlycationEnd Products and its Receptor- Mediated Cardiovascular Disease. Curr Pharm Des 23 (6): 937-943 DOI 10.2174/1381612822666161006 143032
93 Gada E, Owens AW, Gore MO, See R, Abdullah SM, Ayers CR, Rohatgi A, Khera A, de Lemos JA, McGuire DK (2013) Discordant effects of rosiglitazone on novel inflammatory biomarkers. Am Heart J 165 (4): 609-614 DOI 10.1016/j. ahj.2013.01.006

94 张黎军, 李良, 李艳蓉, 邓凯萍 (2007) 罗格列 酩对动脉粥样硬化大鼠血清晚期糖基化终产物 的影响及可能机制。武汉大学学报(医学版) 28 (6) : 737-740

95 谭鸿斌, 姜其钧, 吴建详, 梁春, 刘星, 任雨 笙, 吴宗贵 (2009) 罗格列酮改善晚期糖基化 终产物导致的皮祖细胞功能损伤. 上海医学 32 (4) : 283-288

96 Chiang MC, Cheng YC, Nicol CJ, Lin CH (2017) The neuroprotective role of rosiglitazone in advanced glycation end product treated human neural stem cells is PPARgamma-dependent. Int J Biochem Cell Biol 92: 121-133 DOI 10.1016/j. biocel.2017.09.020

97 Oz Gul O, Tuncel E, Yilmaz Y, Ulukaya E, Gul CB, Kiyici S, Oral AY, Guclu M, Ersoy C, Imamoglu S (2010) Comparative effects of pioglitazone and rosiglitazone on plasma levels of soluble receptor for advanced glycation end products in type 2 diabetes mellitus patients. Metabolism 59 (1): 64-69 DOI 10.1016/j.metabol.2009.07.006

98 Koyama H, Tanaka S, Monden M, Shoji T, Morioka T, Fukumoto S, Mori K, Emoto M, Fukui M, Fujii H, Nishizawa Y, Inaba M (2014) Comparison of effects of pioglitazone and glimepiride on plasma soluble RAGE and RAGE expression in peripheral mononuclear cells in type 2 diabetes: randomized controlled trial (PioRAGE). Atherosclerosis 234 (2): 329-334 DOI 10.1016/j. atherosclerosis.2014.03.025

99 寿砚芸 (2011) 吡格列酩对2型糖尿病患者血清 脂联素、AGEs 、 RANTES、ET及Hcy水平的影响. 河北医科大学学报 32 (4)：380-382

100 Zhao Z, Zhao C, Zhang XH, Zheng F, Cai W, Vlassara H, Ma ZA (2009) Advanced glycation end products inhibit glucose-stimulated insulin secretion through nitric oxide-dependent inhibition of cytochrome c oxidase and adenosine triphosphate synthesis. Endocrinology 150 (6): 2569-2576 DOI 10.1210/en.2008-1342 
Hypoglycemic Drugs and Advanced Glycation Endproducts

101 叶云, 李友元, 邓洪波, 张萍 (2005) 糖尿病鼠 肾组织损伤机制及格列齐特的保护作用。海南 医学 16 (12)：130-131

102 Mamputu JC, Renier G (2002) Advanced glycation end products increase, through a protein kinase C-dependent pathway, vascular endothelial growth factor expression in retinal endothelial cells. Inhibitory effect of gliclazide. J Diabetes Complications 16 (4): 284-293

103 柯剑婷, 李宓, 姜永玮, 许世清, 张文健, 伍 卫，娄晋宁（2013）格列喹酮对GK大鼠糖尿病 肾病的保护作用。中国医院药学杂志 $33(10)$ : 789-792

104 Ke JT, Li M, Xu SQ, Zhang WJ, Jiang YW, Cheng LY, Chen L, Lou JN, Wu W (2014) Gliquidone decreases urinary protein by promoting tubular reabsorption in diabetic Goto-Kakizaki rats. J Endocrinol 220 (2): 129-141 DOI 10.1530/joe13-0199

105 周莉，马丽，孙子林（2008）格列喹酮对糖基 化终产物诱导的人肾系膜细胞RANTES表达的影 响. 中国糖尿病杂志 16 (8): 495-497

106 Nakamura I, Oyama J, Komoda H, Shiraki A, Sakamoto Y, Taguchi I, Hiwatashi A, Komatsu A, Takeuchi M, Yamagishi S, Inoue T, Node K (2014) Possible effects of glimepiride beyond glycemic control in patients with type 2 diabetes: a preliminary report. Cardiovasc Diabetol 13: 15 DOI 10.1186/1475-2840-13-15

107 Beisswenger PJ (2014) Methylglyoxal in diabetes: link to treatment, glycaemic control and biomarkers of complications. Biochem Soc Trans 42 (2): 450-456 DOI 10.1042/bst20130275

108 Agarwal N, Rice SP, Bolusani H, Luzio SD, Dunseath G, Ludgate M, Rees DA (2010) Metformin reduces arterial stiffness and improves endothelial function in young women with polycystic ovary syndrome: a randomized, placebo-controlled, crossover trial. J Clin Endocrinol Metab 95 (2): 722-730 DOI 10.1210/jc.2009-1985

109 张艳华 (2012) 二甲双胍对晚期糖基化终产物 诱导的血管平滑肌细胞增殖的影响. 中国医药 07 (1): 63-64

110 Dziubak A, Wojcicka G (2017) The pathophysiological basis of the protective effects of metformin in heart failure. Postepy Hig Med Dosw (Online) 71 (1): 773-787
111 Diamanti-Kandarakis E, Alexandraki K, Piperi C, Aessopos A, Paterakis T, Katsikis I, Panidis D (2007) Effect of metformin administration on plasma advanced glycation end product levels in women with polycystic ovary syndrome. Metabolism 56 (1): 129-134 DOI 10.1016/j. metabol.2006.09.006

112 李业琼, 叶山东, 翟丽敏, 胡闻 (2016) 二甲 双胍对2型糖尿病模型大鼠肾组织AGEs 表达的影 响. 中国药理学通报 32(9)：703-707

113 周小智, 薛耀明, 高方, 朱波, 矢美萍 (2012) 二甲双胍对AGEs 诱导人结肠癌细胞SW - 480增殖 作用的影响及机制的初探. 中国糖尿病杂志 20 (7) : 546-548

114 王密, 高茑, 间文婷, 周根祥, 刘夏青 (2017) 二甲双胍对骨质疏松大鼠晚期糖基化终产物影 响的研究. 口腔医学研究 33 (5): 479-481

115 Lee TI, Kao YH, Chen YC, Huang JH, Hsu MI, Chen YJ (2013) The dipeptidyl peptidase-4 inhibitorsitagliptin modulates calcium dysregulation, inflammation, and PPARs in hypertensive cardiomyocytes. Int J Cardiol 168 (6): 5390-5395 DOI 10.1016/j.ijcard.2013.08.051

116 江颖娟, 蒋作锋, 吴小兰, 黄珮, 吴文法, 余慧 文 (2017) 西格列汀对AGEs作用下系膜细胞自 噬的影响. 中国病理生理杂志 33 (8)：14551459

117 Jung E, Kim J, Kim SH, Kim S, Cho MH (2014) Gemigliptin, a novel dipeptidyl peptidase-4 inhibitor, exhibits potent anti-glycation properties in vitro and in vivo. Eur J Pharmacol 744: 98-102 DOI 10.1016/j.ejphar.2014.10.008

118 Matsui T, Nishino Y, Takeuchi M, Yamagishi S (2011) Vildagliptin blocks vascular injury in thoracic aorta of diabetic rats by suppressing advanced glycation end product-receptor axis. Pharmacol Res 63 (5): 383-388 DOI 10.1016/j. phrs.2011.02.003

119 Ishibashi Y, Matsui T, Maeda S, Higashimoto Y, Yamagishi S (2013) Advanced glycation end products evoke endothelial cell damage by stimulating soluble dipeptidyl peptidase-4 production and its interaction with mannose 6-phosphate/insulin-like growth factor II receptor. Cardiovasc Diabetol 12: 125 DOI 10.1186/1475-2840-12-125 
Hypoglycemic Drugs and Advanced Glycation Endproducts

120 Nakashima S, Matsui T, Takeuchi M, Yamagishi SI (2014) Linagliptin blocks renal damage in type 1 diabetic rats by suppressing advanced glycation end products-receptor axis. Horm Metab Res 46 (10): 717-721 DOI 10.1055/s-0034-1371892

121 Sakata K, Hayakawa M, Yano Y, Tamaki N, Yokota $\mathrm{N}$, Eto T, Watanabe R, Hirayama N, Matsuo T, Kuroki K, Sagara S, Mishima O, Koga M, Nagata N, Nishino Y, Kitamura K, Kario K, Takeuchi M, Yamagishi S (2013) Efficacy of alogliptin, a dipeptidyl peptidase-4 inhibitor, on glucose parameters, the activity of the advanced glycation end product (AGE) - receptor for AGE (RAGE) axis and albuminuria in Japanese type 2 diabetes. Diabetes Metab Res Rev 29 (8): 624630 DOI 10.1002/dmrr.2437

122 Ojima A, Ishibashi Y, Matsui T, Maeda S, Nishino Y, Takeuchi M, Fukami K, Yamagishi S (2013) Glucagon-like peptide-1 receptor agonist inhibits asymmetric dimethylarginine generation in the kidney of streptozotocin-induced diabetic rats by blocking advanced glycation end productinduced protein arginine methyltranferase-1 expression. Am J Pathol 182 (1): 132-141 DOI 10.1016/j.ajpath.2012.09.016

123 Nguyen DV, Linderholm A, Haczku A, Kenyon N (2017) Glucagon-like peptide 1: A potential antiinflammatory pathway in obesity-related asthma. Pharmacol Ther 180: 139-143 DOI 10.1016/j. pharmthera.2017.06.012

124 Zhan Y, Sun HL, Chen H, Zhang H, Sun J, Zhang Z, Cai DH (2012) Glucagon-like peptide-1 (GLP-1) protects vascular endothelial cells against advanced glycation end products (AGEs)-induced apoptosis. Med Sci Monit 18 (7): BR286-291

125 Ishibashi Y, Matsui T, Takeuchi M, Yamagishi S (2010) Glucagon-like peptide-1 (GLP-1) inhibits advanced glycation end product (AGE)induced up-regulation of VCAM-1 mRNA levels in endothelial cells by suppressing AGE receptor (RAGE) expression. Biochem Biophys Res Commun 391 (3): 1405-1408 DOI 10.1016/j. bbrc.2009.12.075

126 DoreckaM,SiemianowiczK,FrancuzT,GarczorzW, Chyra A, Klych A, Romaniuk W (2013) Exendin-4 and GLP-1 decreases induced expression of ICAM-1, VCAM-1 and RAGE in human retinal pigment epithelial cells. Pharmacol Rep 65 (4): 884-890

127 Chang JT, Liang YJ, Hsu CY, Chen CY, Chen PJ, Yang YF, Chen YL, Pei D, Chang JB, Leu JG (2017) Glucagon-like peptide receptor agonists attenuate advanced glycation end productsinduced inflammation in rat mesangial cells. BMC Pharmacol Toxicol 18 (1): 67 DOI 10.1186/ s40360-017-0172-3

128 李沛城, 冯波 (2016) 利拉鲁肽下调糖尿病 ApoE - / - 小鼠主动脉糖基化终产物受体表达并 减轻动脉粥样硬化. 中华内分泌代谢杂志 32 (8) : 680-684

129 Li P, Tang Z, Wang L, Feng B (2017) Glucagonlike peptide- 1 analogue liraglutide ameliorates atherogenesis via inhibiting advanced glycation end product-induced receptor for advanced glycosylation end product expression in apolipoprotein-E deficient mice. Mol Med Rep 16 (3): 3421-3426 DOI 10.3892/mmr.2017.6978

130 Steven S, Oelze M, Hanf A, Kroller-Schon S, Kashani F, Roohani S, Welsch of P, Kopp M, GodtelArmbrust U, Xia N, Li H, Schulz E, Lackner KJ, Wojnowski L, Bottari SP, Wenzel P, Mayoux E, Munzel T, Daiber A (2017) The SGLT2 inhibitor empagliflozin improves the primary diabetic complications in ZDF rats. Redox Biol 13: 370385 DOI 10.1016/j.redox.2017.06.009

131 Oelze M, Kroller-Schon S, Welschof P, Jansen T, Hausding M, Mikhed Y, Stamm P, Mader M, Zinssius E, Agdauletova S, Gottschlich A, Steven S, Schulz E, Bottari SP, Mayoux E, Munzel T, Daiber A (2014) The sodium-glucose cotransporter 2 inhibitor empagliflozin improves diabetes-induced vascular dysfunction in the streptozotocin diabetes rat model by interfering with oxidative stress and glucotoxicity. PLoS One 9 (11): e112394 DOI 10.1371/journal. pone.0112394

132 Ojima A, Matsui T, Nishino Y, Nakamura N, Yamagishi S (2015) Empagliflozin, an Inhibitor of Sodium-Glucose Cotransporter 2 Exerts Anti-Inflammatory and Antifibrotic Effects on Experimental Diabetic Nephropathy Partly by Suppressing AGEs-Receptor Axis. Horm Metab Res 47 (9): 686-692 DOI 10.1055/s-00341395609 
Hypoglycemic Drugs and Advanced Glycation Endproducts

133 Tan KC, Shiu SW, Wong Y, Tam X (2011) Serum advanced glycation end products (AGEs) are associated with insulin resistance. Diabetes Metab Res Rev 27 (5): 488-492 DOI 10.1002/ dmrr.1188

134 Jia X, Wu L (2007) Accumulation of endogenous methylglyoxal impaired insulin signaling in adipose tissue of fructose-fed rats. Mol Cell Biochem 306 (1-2): 133-139 DOI 10.1007/ s11010-007-9563-x

135 Cai W, Ramdas M, Zhu L, Chen X, Striker GE, Vlassara H (2012) Oral advanced glycation endproducts (AGEs) promote insulin resistance and diabetes by depleting the antioxidant defenses AGE receptor-1 and sirtuin 1. Proc Natl Acad Sci U S A 109 (39): 15888-15893 DOI 10.1073/pnas.1205847109

136 Naitoh T, Kitahara M, Tsuruzoe N (2001) Tumor necrosis factor-alpha is induced through phorbol ester--and glycated human albumin-dependent pathway in THP-1 cells. Cell Signal 13 (5): 331334

137 Miele C, Riboulet A, Maitan MA, Oriente F, Romano C, Formisano P, Giudicelli J, Beguinot F, Van Obberghen E (2003) Human glycated albumin affects glucose metabolism in L6 skeletal muscle cells by impairing insulin-induced insulin receptor substrate (IRS) signaling through a protein kinase $\mathrm{C}$ alpha-mediated mechanism. J Biol Chem 278 (48): 47376-47387 DOI 10.1074/ jbc.M301088200
138 Cassese A, Esposito I, Fiory F, Barbagallo AP, Paturzo F, Mirra P, Ulianich L, Giacco F, Iadicicco C, Lombardi A, Oriente F, Van Obberghen E, Beguinot F, Formisano P, Miele C (2008) In skeletal muscle advanced glycation end products (AGEs) inhibit insulin action and induce the formation of multimolecular complexes including the receptor for AGEs. J Biol Chem 283 (52): 36088-36099 DOI 10.1074/jbc.M801698200

139 Boyd AC, Abdel-Wahab YH, McKillop AM, McNulty H, Barnett CR, O'Harte FP, Flatt PR (2000) Impaired ability of glycated insulin to regulate plasma glucose and stimulate glucose transport and metabolism in mouse abdominal muscle. Biochim Biophys Acta 1523 (1): 128-134

140 Hunter SJ, Boyd AC, O'Harte FP, McKillop AM, Wiggam MI, Mooney MH, McCluskey JT, Lindsay JR, Ennis CN, Gamble R, Sheridan B, Barnett CR, McNulty H, Bell PM, Flatt PR (2003) Demonstration of glycated insulin in human diabetic plasma and decreased biological activity assessed by euglycemic-hyperinsulinemic clamp technique in humans. Diabetes 52 (2): 492-498

141 Jia X, Olson DJ, Ross AR, Wu L (2006) Structural and functional changes in human insulin induced by methylglyoxal. FASEB J 20 (9): 1555-1557 DOI 10.1096/fj.05-5478fje

Citation: Wen Xiong, Zhiqiang Zhou, Xiandang Zhang. Hypoglycemic Drugs and Advanced Glycation Endproducts. Archives of Diabetes and Endocrine System. 2020; 3(1): 12-26.

Copyright: (c) 2020 Wen Xiong, Zhiqiang Zhou, Xiandang Zhang. This is an open access article distributed under the Creative Commons Attribution License, which permits unrestricted use, distribution, and reproduction in any medium, provided the original work is properly cited.

Archives of Diabetes and Endocrine System V3 . I1 . 2020 